\title{
Support method for interpretation of regional groundwater monitoring in urban areas
}

\author{
Fabio Pileggi' (D), Ricardo Hirata' (D), Nataly $\operatorname{Aranda}^{2}$ (D), Bruno Conicelli ${ }^{1,2 *}$ (D)
}

\begin{abstract}
Urban centers radically alter hydrological cycles, causing unintended consequences for the environment, such as the creation of extensive contamination plumes in unconfined aquifers. The Environmental Agency of the State of São Paulo has observed this issue since 1994. Therefore, this study aimed to create a method using nitrate as an indicator of contamination that permits an assertive interpretation of changes in the groundwater quality in monitoring wells of regional networks. The method was applied in ten cities with monitoring wells in the Bauru Aquifer System. The results correlated the presence of nitrate with the time and dynamics of land use in the capture zones of the wells over 54 years (1962-2016). In areas with sewer networks installed before 2001 and urban occupation greater than $60 \%$ of urban occupation in the capture zones, there was an increase in nitrate concentration of at least $35 \%$. Likewise, extending this new method to other wells will make it possible to identify the causes of nitrate and other contaminants in the groundwater-monitoring network in the State of São Paulo.
\end{abstract}

KEYWORDS: groundwater; nitrate; aquifer monitoring network; land use and occupation; urban planning.

\section{INTRODUCTION}

Cities have radically altered the flow of water, energy, and matter from river basins. Waterproofing the land increases rain interception and runoff and reduces aquifer recharge. Similarly, cities modify the heat flow and, consequently, water evaporation processes and rain patterns. Equally important, various urban activities transfer immense amounts of matter from the atmosphere (Babinski et al. 2003, 2012) and from the surface to the soil (CETESB 2013, Santos Filho et al.2017, Aranda et al. 2019), rivers (Porto 2003, Xu et al. 2019), and aquifers (Foster and Hirata 1988, DAEE 2012, Cary et al. 2013, Conicelli 2014, Bertolo et al. 2015, Hirata et al. 2015, Petelet-Giraud et al. 2018), sometimes contaminating them. In this urban cycle of water, energy, and matter, one of the rarely researched components is the aquifer (Foster et al.2011, Hibbs and Sharp 2012, Hirata and Suhogusoff 2019), even in countries in Europe and North America.

In Brazil, in recent decades, cities have faced problems related to drastic increases in the concentration of pollutants in aquifers, including nitrate (Hirata and Suhogusoff 2019, Varnier et al. 2019). The origins of this contaminant in aquifers are associated with poor agricultural practices, including over-application of inorganic fertilizers, infiltration of sewers

${ }^{1}$ Centro de Pesquisas de Águas Subterrâneas, Universidade de São Paulo São Paulo (SP), Brazil. E-mails: fabiolp1@hotmail.com, rhirata@usp.br

${ }^{2}$ Universidad Regional Amazonica Ikiam - Parroquia Muyuna, Tena, Napo, Ecuador. E-mails: aranda.nata@gmail.com, bconicelli@gmail.com ${ }^{*}$ Corresponding author.

(c) 2021 The authors. This is an open access article distributed under the terms of the Creative Commons license. in urban areas, and extensive industrial activities (Foster et al. 2006, Reynolds-Vargas et al. 2006, He and Wu 2019, Wu et al. 2020). Despite the numerous cases of nitrate described in the State of São Paulo, as in Marília (Varnier et al. 2010), São José do Rio Preto (Barcha 1980), and Bauru (Hirata 2000, Giafferis and Oliveira 2006), this problem remains underestimated by public authorities and even more by groundwater users (Varnier et al. 2019). This issue has been systematically documented in the Environmental Sanitation Technology Company (CETESB) triennial reports - Quality of Groundwater in the State of São Paulo. Nevertheless, no studies have explained the causes behind the increase of nitrate concentrations in the monitoring network over time; and reports have only attempted to describe the problem.

The best way to reduce the nitrate contamination risk in urban aquifers is to construct sewer networks, whose service reaches more than 38 million of the São Paulo population (88.4\%) (SNIS 2017). However, leaks from the sewer mains are responsible for extensive contamination in unconfined aquifers (Hirata et al. 2015, Hirata and Suhogusoff 2019, Varnier et al. 2019), which is worrisome, especially when $80 \%$ of the state cities state have total or partial public water supply from groundwater, in addition to the existence of hundreds of thousands of private tubular wells that are extensively used.

The presence of nitrate in a specific well, which extracts water from an unconfined aquifer, is a function of contamination sources in its nearby recharge area (Drake and Bauder 2005, Reynolds-Vargas et al. 2006, Xu et al. 2007). These studies maintain that higher nitrate concentrations are associated with sites whose sewage collection network is old, poorly maintained and leaks or contains cesspools and septic tanks to drain domestic effluents (Hirata et al. 2015). 
An additional problem related to regional monitoring networks, such as those operated by CETESB, is their low assertiveness levels. Monitoring wells can only assess what is happening in their immediate area (Foster and Gomes 1989), not exceeding a few hundred meters. Also, São Paulo network uses tubular production wells, usually with long screen intervals, which cause a mixture of waters of varying ages and chemical compositions. Generally, deeper levels with clean waters mask shallower portions of the heavily contaminated aquifer.

Therefore, this paper aimed to create a methodology that generates more assertive results obtained by a regional monitoring network, allowing the establishment of a relation between land occupation and deterioration of the quality of aquifers caused by urban sources, using nitrate as a chemical indicator.

\section{STUDY AREA}

The geological framework of the State of São Paulo allows the aquifers to be divided into two groups: those of primary porosity, represented by sedimentary aquifers (Furnas, Itararé, Aquidauana, Passa Dois, Botucatu, Piramboia, Santo Anastácio, Caiuá, Marília, Adamantina, São Paulo, Litorâneo, and Taubaté) and undifferentiated cenozoic coverings; and secondary porosity aquifers, represented by the fractured Serra Geral and Cristalino (DAEE 2005). These aquifers are aggregated into aquifer systems, namely Cenozoic, Bauru, Serra Geral, Guarani, Aquitarde Passa Dois, Tubarão, Paraná, and Cristalino (Carvalho and Hirata 2012).

The Bauru Aquifer System (BAS), which is the focus of this study, occupies around the Western half of the State of São Paulo, with an area of $96,880 \mathrm{~km}^{2}$, as in Fig. 1 (Varnier et al. 2010). It consists of the Bauru Groups rocks, whose continental fluvial

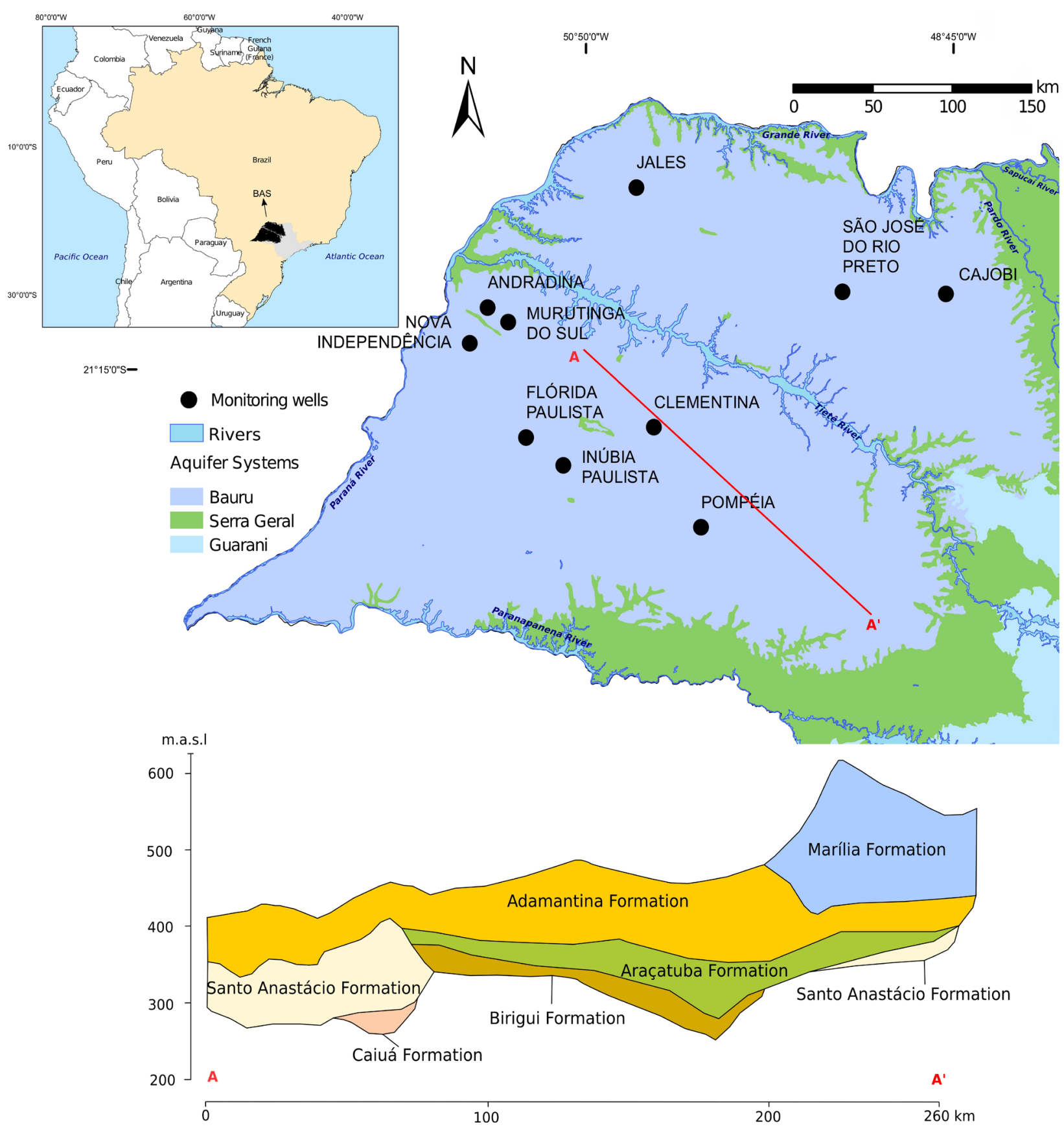

Figure 1. Study area and location of the monitoring wells considered in this paper (modified from DAEE 2005) and NE-SE cross-sections showing thicknesses and contacts of the Bauru Group (modified from Paula and Silva 2003). 
sedimentation occurred in desert conditions and at a semi-arid climate, providing it lithological heterogeneity. The primary lithologies of this unit are sandstones, clayey sandstones, and siltstones, with or without carbonate cementation, characterized as a predominantly unconfined hydrogeological body that is a locally semi-confined one (DAEE 2005). Due to its extent and good productivity, it is the most intense and extensively explored system and is a water source for most of the municipalities in Western São Paulo.

The aquifers part of the BAS are Marília, Adamantina, Santo Anastácio, and Caiuá (Tab. 1). According to CETESB (2019), its waters are predominant of two hydrochemical types, calcium bicarbonates (43\%) and mixed type (37\%) and, secondarily, sodium bicarbonates (17\%). With the exception of local natural problems of iron, manganese, (more locally) chromium (Bourotte et al. 2009) and barium (Tavares et al. 2015) anomalies, its water is of excellent quality and is drinkable in more than $95 \%$ of the locations.

The BAS has an average saturated thickness of $75 \mathrm{~m}$ and can vary from 150 to $200 \mathrm{~m}$ in the region of São José do Rio Preto and Presidente Prudente, and to $300 \mathrm{~m}$ in the Residual Plateau of Marília. Thickness is influenced by the morphology of the rocky substrate represented by the basalts of Serra Geral Formation. Recharge occurs directly due to rainfall, and the groundwater regional flow takes place towards the main drains of Turvo, São José dos Dourados, Tietê, Aguapeí, Peixe, Santo Anastácio, Paraná, and Paranapanema rivers. The exploitable flow varies from 10 to $120 \mathrm{~m}^{3} / \mathrm{h}$ per well, with higher potential zones located along the Paraná and Paranapanema rivers.

\section{MATERIALS AND METHODS}

The method to monitor the nitrate concentration in the BAS consisted of two main stages, the selection and mapping of the wells and the comparison and chemical and urban occupation data correlation of the wells (Fig. 2). After selecting the wells, the next step was to map the capture zone for each well. Then, in each capture zone, changes in occupation between 1962 and 2016 were identified in the aerial images. The second stage compared and correlated the urban occupation, the sewer network installation year, and chemical data between 1962 and 2016.

\section{Physical-chemical data of the monitoring network}

Groundwater-monitoring network data of the State of São Paulo covered 1994 to 2015 (CETESB 2013, 2016, 2019). Groundwater was collected and analyzed by CETESB and included 67 physical, chemical, and bacteriological parameters (Tab.2). The monitoring network consists of active tubular water production wells equipped with submerged electric pumps.

The program used for calculating the variation in nitrate concentrations overtime was Microsoft Excel. The groundwater collection frequency was one to three times a year, with sampling carried out according to the hydrological cycle, usually in a dry period (May to October) and a rainy one (November to April). The tubular wells were included in the network at different times, generating varied sampling periods. Given the wealth of chemical data, we sought to associate the various parameters with one another using correlation diagrams for each well. Positive, negative, or null $\rho$ correlations were established according to the method described by Pearson (Freedman et al.2007), as seen in Equation 1:

$$
\rho=\frac{\sum_{i=1}^{n}\left(x_{i}-\bar{x}\right)\left(y_{i}-\bar{y}\right)}{\sqrt{\left[\sum_{i=1}^{n}\left(x_{i}-\bar{x}\right)^{2}\right]\left[\sum_{i=1}^{n}\left(y_{i}-\bar{y}\right)^{2}\right]}}
$$

The values of $\rho$ are interpreted as follows:

- $\rho=1$ means a perfect direct correlation between the two variables;

- $\rho=-1$ means a perfect inverse correlation between the two variables, that is, if one increases, the other always decreases;

- $\rho=0$ means that the two variables do not depend linearly on each other.

\section{Well identification}

Currently, the aquifer-monitoring network of the São Paulo State comprises a total of 313 tubular wells distributed over the main aquifer systems (CETESB 2019). Two public reports were evaluated for this study: CETESB (2013) and CETESB (2016), which highlight the main wells in the State of São Paulo with nitrate concentrations above $5 \mathrm{mg} / \mathrm{L} \mathrm{N}-\mathrm{NO}_{3}$.

The BAS is the main water unit affected by nitrate in the State of São Paulo (CETESB 2016). Ten wells located in this aquifer system were chosen to correlate land use and nitrate

Table 1. Hydrogeological parameters of the aquifers of the Bauru Aquifer System in the State of São Paulo.

\begin{tabular}{|c|c|c|c|c|c|c|c|c|c|c|}
\hline \multirow{2}{*}{$\begin{array}{l}\text { Aquifer } \\
\text { System }\end{array}$} & \multirow[b]{2}{*}{ Aquifer } & \multirow[b]{2}{*}{ Description } & \multicolumn{8}{|c|}{ Hydrogeological properties } \\
\hline & & & $\begin{array}{c}\text { Area } \\
\left(\mathbf{k m}^{2}\right)\end{array}$ & $\underset{\left(\mathbf{m}^{3} / \mathbf{h}\right)}{\mathbf{Q}}$ & $\mathbf{n}(\%)$ & $\mathbf{b}(\mathbf{m})$ & $\begin{array}{c}\mathbf{K} \\
(\mathbf{m} / \mathbf{d})\end{array}$ & $\mathbf{i}$ & $\begin{array}{l}\mathbf{n}_{\text {ef }} \\
(\%)\end{array}$ & $\begin{array}{l}\text { Recharge } \\
(\mathbf{m m} / \text { year })\end{array}$ \\
\hline \multirow{4}{*}{ Bauru } & Marília & $\begin{array}{l}\text { Regional extension, } \\
\text { granular, free to semi- }\end{array}$ & 15,000 & 7.5 & 0.13 & 120 & 1 & 0.04 & 0.1 & 250 \\
\hline & Adamantina & $\begin{array}{l}\text { confined, discontinuous, } \\
\text { heterogeneous, anisotropic }\end{array}$ & 104,000 & 19 & 0.15 & 130 & 1.5 & 0.03 & 0.1 & 250 \\
\hline & $\begin{array}{c}\text { Santo } \\
\text { Anastácio }\end{array}$ & $\begin{array}{l}\text { Limited extension, } \\
\text { granular, free to semi- }\end{array}$ & 67,000 & 35 & 0.25 & 80 & 2 & 0.02 & 0.12 & 250 \\
\hline & Caiuá & $\begin{array}{l}\text { confined, discontinuous, } \\
\text { heterogeneous, anisotropic }\end{array}$ & 13,000 & 100 & 0.2 & 100 & 2.5 & 0.01 & 0.15 & 350 \\
\hline
\end{tabular}

Q: flow rate (considering 24 hours pumping); $n$ : total porosity; b: saturated thickness; $\mathrm{K}$ : hydraulic conductivity; i: hydraulic gradient; $\mathrm{n}_{\mathrm{ef}}$ : effective porosity. Source: modified from Carvalho and Hirata 2012. 
concentrations. The selected wells are located mainly in the Adamantina Aquifer, followed by Santo Inácio and Caiuá aquifers. The information available for the ten selected wells includes:

- increase, decrease, or neutral/stable nitrate concentration overtime;

- location of the wells that allows to make a correlation with the evolution of land occupation;

- complete and reliable construction information;

- consistency in the variation of nitrate concentrations in several campaigns.

The average concentration for two different periods was determined and compared in order to evaluate the changes in nitrate concentration for each selected well: the first six years of well operation and between 2009 and 2015 .

\section{Mapping of capture zones in wells}

The method used to establish the capture zones (related to recharge) of the well was the calculated fixed radius (CFR), which is defined through the transit time of 50 years, in agreement with the time of comparison between the images of the $60 \mathrm{~s}$ and the last collection evaluated in 2016.
The CFR method (Fig. 3 and Eq. 2) is based on a geometric approach that defines a circular area around the well proportional to the volume of water withdrawn in a particular period (USEPA 1994, Carvalho and Hirata 2012). This technique does

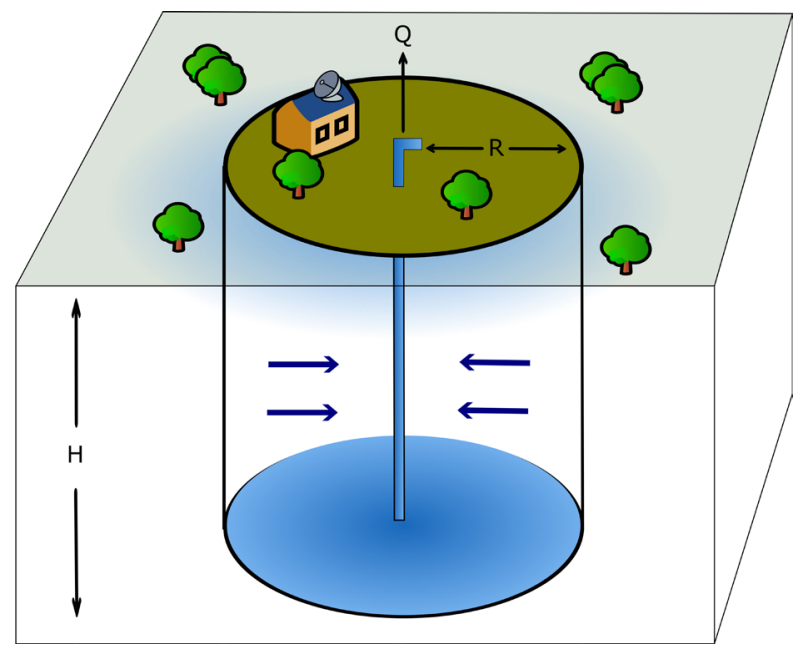

Source: adapted from USEPA (1994).

Figure 3. Outline of the well protection perimeter using the calculated fixed radius method. The variables are the same as in Equation 2.

\section{SELECTION OF WELLS}

10 wells in the Bauru Aquifer System

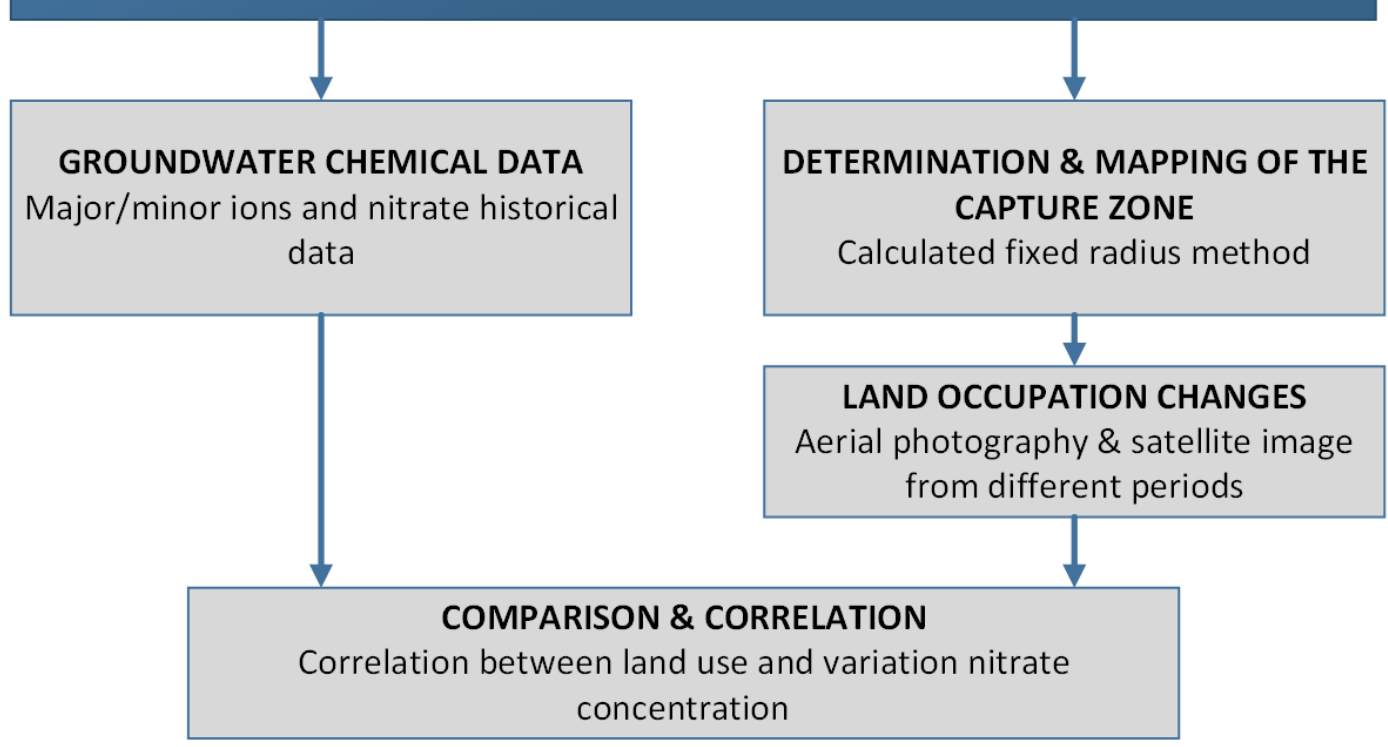

Figure 2. Diagram summarizing the methodology.

Table 2. Physical-chemical and microbiological parameters analyzed in the groundwater in the State of São Paulo monitoring network.

\begin{tabular}{lcc}
\hline Physical & Chemical & Microbiological \\
\hline & pH, alkalinity bicarbonate, alkalinity carbonate, alkalinity hydroxide, \\
electrical conductivity, total hardness, nitrogen nitrate, nitrogen nitrite, \\
ammoniacal nitrogen, Kjeldhal nitrogen, dissolved organic carbon, \\
chloride, fluoride, sulfate, aluminum, antimony, arsenic, barium, Heterotrophic bacteria, \\
Water and air temperature, & $\begin{array}{c}\text { Escherichia coli, total } \\
\text { total dissolved and total solids } \\
\text { hexavalent chromium, tin, strontium, iron, lithium, magnesium, } \\
\text { manganese, mercury, molybdenum, nickel, potassium, silver, selenium, } \\
\text { sodium, titanium, uranium, vanadium, and zinc }\end{array}$ \\
\hline
\end{tabular}


not consider the conditions of heterogeneity, anisotropy, or direction of aquifer flow, nor other particularities of the outline of wells. The CFR defines a capture zone that corresponds to a very simplified reality; however, the method is quite useful with a first assessment, especially in smooth topographical relief and few geological data (Carvalho and Hirata 2012).

$$
R=\sqrt{\frac{Q t}{\pi H n_{e f}}}
$$

Where:

$R$ is the calculated fixed radius;

$t$ is the travel time;

$Q$ is the pumping rate;

$H$ is the thickness of the aquifer saturated zone;

$\mathrm{n}_{\text {ef }}$ is the effective porosity (Fig. 3).

The method applied the information of the following:

- well yield;

- effective porosity;

- thickness of the aquifers saturated zone, which were taken from the construction profiles of the wells, as well as from the geology of the lithostratigraphic units.

The capture zones were calculated using the average effective porosity of the respective aquifers (Tab. 1), and the flow and saturated thickness were obtained from the construction profiles of wells.

\section{Sewer network installation year}

The sewer mains in the capture zones of the selected wells were obtained through interviews with the service operators

\section{a)}

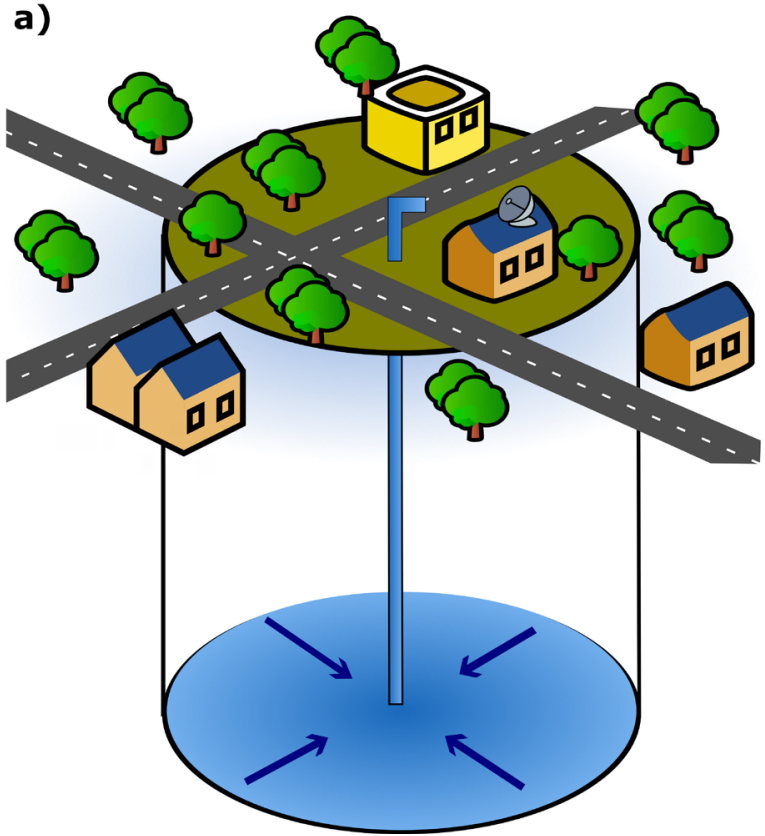

in each city and presented different installation dates, starting in 1962 (Andradina, Flórida Paulista, Inúbia Paulista) until 2000 (Jales and São José do Rio Preto). The other cities had their sewer network installed after 2001; the most recent being Clementina, Nova Independência, and Murutinga do Sul.

\section{Aerial photo analysis and images}

The images were manipulated using Google Earth Pro and ArcMap 10.4.1, whose features allowed the integration and comparison between:

- 1:25,000 panchromatic aerial photographs, from an August 1962 aerial photographic survey by the São Paulo State Secretariat of Agriculture (São Paulo 1962), which were kindly provided by the Aerial Photography and Remote Sensing Laboratory (LASERE) of Universidade de São Paulo;

- satellite images from the 2000 s onwards from the Landsat program (Land Remote Sensing Satellite), owned by the US government, and extracted from Google Earth Pro.

The comparison between the images determined the evolution and patterns of occupation throughout the extension of the capture zone (Fig. 4). It was possible to establish the variation in occupation, with special attention to the:

- type of land occupation;

- urban occupation density (houses/area of the capture zone), through the counting of roofs;

- presence and assessment of green zones (drainages, rivers, native vegetation).

\section{RESULTS}

The analyzed wells are in the urban area of the cities indicated in Table 3. The results revealed three types of behaviors

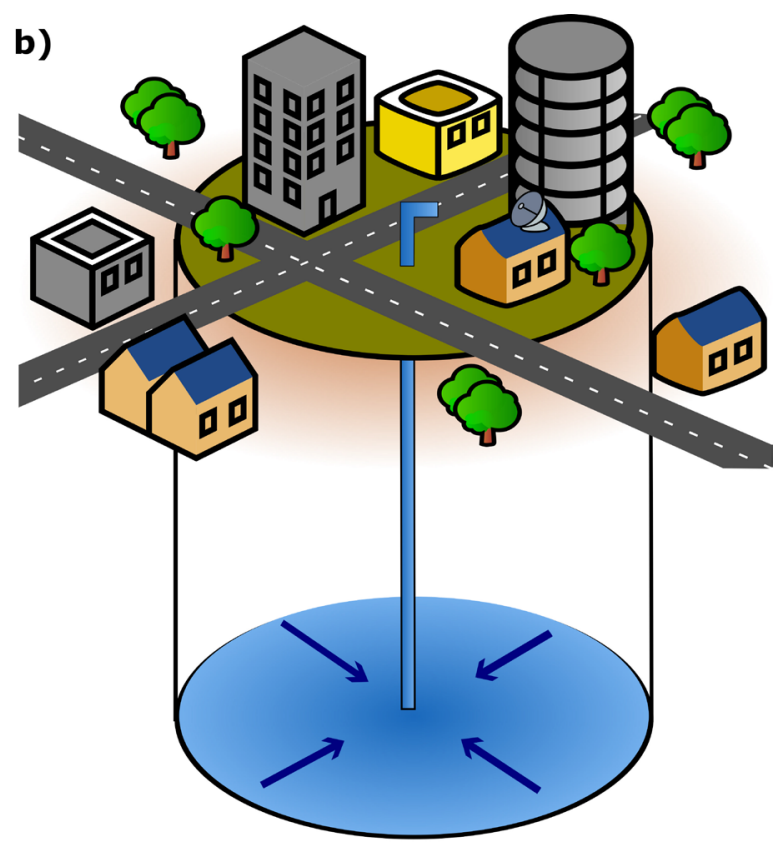

Figure 4. (A) Scheme for assessing the evolution of capture zone occupation patterns considered the type of land occupation, density of buildings, and recognition of natural zones, based on a comparison of aerial photographs from 1962. The blue color near the surface represents water without the presence of nitrate. (B) satellite images from the 2000s onward. The brown color near the surface indicates the presence of nitrate. 
overtime (Tab. 3): three wells with a tendency toward decreased concentration (Cajobi, Murutinga do Sul, and Pompéia); a well showing stable behavior (Inúbia Paulista); and six wells with a tendency toward increased concentration (Andradina, Clementina, Florida Paulista, Jales, Nova Independência, and São José do Rio Preto). The average radius values of the capture zones were $532 \mathrm{~m}$, with highs and lows of 799 (Andradina) and $314 \mathrm{~m}$ (Pompéia), respectively (Tab. 4).

Urban occupation (Tab. 5) was estimated by counting buildings (houses or service facilities) located in the capture zone of each well, constituting a relationship between the number of houses or building $/ \mathrm{km}^{2}$ (Fig. 5). In all the studied cities, the urban density in the capture zone area increased between 132\% (Inúbia Paulista) and 730\% (São José do Rio Preto).

The highest values of urban density in 1962 were found in places whose age of occupation was older, that is, in the portions close to each city's center. By contrast, the wells installed in these places showed the smallest increases in urbanization because they were already substantially occupied.
The 2016 images show that the predominant occupation was urban, except in Cajobi and Nova Independência, where there are significant green areas. Urban areas predominated in a large part of the capture zone, with urban occupation rates of $30 \%$ in Cajobi and $45 \%$ in Nova Independência. The locations of São José do Rio Preto, Jales, and Flórida Paulista had $100 \%$ urban occupation.

Pearson's method determined the correlations among the 67 physical, chemical, and bacteriological parameters, and nitrate, seeking to better understand the nitrate origin (Tab.6). However, although there were some significant direct and inverse correlations with other chemical parameters, few conclusions could be drawn. In Jales, there was a negative correlation $(\rho=-0.7)$ between nitrate and hexavalent chromium, as this contaminant has a natural origin. As nitrate is a contaminant of anthropic origin, its concentration is higher in the aquifer's most superficial portions. On the other hand, the hexavalent chromium is found at aquifer greater depths, denoting a longer water-transit time (Bertolo et al. 2011). In the

Table 3. Average nitrate concentration for the first six years of well operation and the 2009-2015 period for the ten selected wells.

\begin{tabular}{|c|c|c|c|c|c|c|}
\hline Town & $\begin{array}{l}\text { CETESB } \\
\text { well code }\end{array}$ & $\begin{array}{c}\text { First year of } \\
\text { operation }\end{array}$ & $\begin{array}{l}\text { Average nitrate } \\
\text { concentrations } \\
\text { in the first six } \\
\text { years of operation } \\
\left(\mathrm{mg} / \mathrm{L} \mathrm{N}-\mathrm{NO}_{3}\right)\end{array}$ & $\begin{array}{c}\text { Average nitrate } \\
\text { Concentrations } \\
\text { from } 2009 \text { to } 2015 \\
\left(\mathrm{mg} / \mathrm{L} \mathrm{N}-\mathrm{NO}_{3}\right)\end{array}$ & $\begin{array}{c}\text { Variation } \\
\text { of nitrate } \\
\text { concentrations }\end{array}$ & Variation \\
\hline Andradina & BA0006P & 1993 & 8.36 & 16.20 & $+94 \%$ & Increase \\
\hline Cajobi & BA0023P & 1994 & 6.32 & 3.28 & $-48 \%$ & Decrease \\
\hline Clementina & BA0028P & 1993 & 3.71 & 6.58 & $+77 \%$ & Increase \\
\hline Flórida Paulista & BA0040P & 1993 & 1.48 & 6.31 & $+326 \%$ & Increase \\
\hline Inúbia Paulista & BA0052P & 1992 & 8.08 & 7.57 & $-6 \%$ & Stable \\
\hline Jales & BA0059P & 1993 & 5.59 & 7.57 & $+35 \%$ & Increase \\
\hline Murutinga do Sul & BA0076P & 1993 & 8.30 & 5.39 & $-35 \%$ & Decrease \\
\hline Nova Independência & BA0079P & 1993 & 2.45 & 5.08 & $+107 \%$ & Increase \\
\hline Pompéia & BA0203P & 1998 & 7.44 & 3.80 & $-49 \%$ & Decrease \\
\hline São José do Rio Preto & BA0127P & 1993 & 2.17 & 8.79 & $+305 \%$ & Increase \\
\hline
\end{tabular}

Table 4. Identification of parameters for calculating the capture zones of the selected wells.

\begin{tabular}{|c|c|c|c|c|c|c|c|c|c|c|c|c|c|c|}
\hline Town & $\begin{array}{l}\text { Aquifer } \\
\text { system }\end{array}$ & Aquifer & UTM N & UTME & $\begin{array}{c}\text { Well } \\
\text { depth } \\
\text { (m.b.g.l) }\end{array}$ & $\begin{array}{c}\text { Screen } \\
\text { level } \\
\text { depth } \\
\text { (m.b.g.l) }\end{array}$ & $\begin{array}{c}\text { Static } \\
\text { level } \\
\text { (m.b.g.l) }\end{array}$ & $\begin{array}{c}\text { CFR } \\
(50 \\
\text { years }) \\
(\mathbf{m})\end{array}$ & $\underset{\left(\mathbf{m}^{3} / \mathbf{d}\right)}{\mathbf{Q}}$ & $\begin{array}{c}\mathbf{b} \\
(\mathbf{m})\end{array}$ & $\begin{array}{c}\mathbf{K} \\
(\mathbf{m} / \mathbf{d})\end{array}$ & i & $\begin{array}{c}\mathbf{n}_{\text {ef }} \\
(\%)\end{array}$ & $\begin{array}{c}\text { Recharge } \\
\text { (mm/ } \\
\text { year) }\end{array}$ \\
\hline Andradina & & Adamantina & 7687350 & 459600 & 105 & $54-102$ & 26 & 799 & 1,032 & 94 & 1.5 & 0.03 & 0.1 & 250 \\
\hline Cajobi & & Adamantina & 7693900 & 729750 & 112 & $5-112$ & 63 & 608 & 312 & 49 & 1.5 & 0.03 & 0.1 & 250 \\
\hline Clementina & & Adamantina & 7615650 & 557350 & 94,5 & $22-84$ & 33 & 405 & 144 & 51 & 1.5 & 0.03 & 0.1 & 250 \\
\hline $\begin{array}{l}\text { Flórida } \\
\text { Paulista }\end{array}$ & & Adamantina & 7609600 & 482250 & 200 & $81-195$ & 14 & 450 & 384 & 110 & 1.5 & 0.03 & 0.1 & 250 \\
\hline Inúbia Paulista & & Adamantina & 7592750 & 504050 & 220 & $70-204$ & 42 & 394 & 432 & 162 & 1.5 & 0.03 & 0.1 & 250 \\
\hline Jales & Bauru & Adamantina & 7759100 & 547675 & 145 & $36-142$ & 19 & 593 & 744 & 123 & 1.5 & 0.03 & 0.1 & 250 \\
\hline $\begin{array}{l}\text { Murutinga } \\
\text { do Sul }\end{array}$ & & Adamantina & 7678650 & 471750 & 140 & $35-130$ & 15 & 365 & 264 & 115 & 1.5 & 0.03 & 0.1 & 250 \\
\hline $\begin{array}{l}\text { Nova } \\
\text { Independência }\end{array}$ & & $\begin{array}{c}\text { Santo } \\
\text { Anastácio }\end{array}$ & 7665750 & 449100 & 91 & $32-86$ & 7 & 767 & 960 & 79 & 2 & 0.02 & 0.1 & 250 \\
\hline Pompéia & & Marília & 7555540 & 584827 & 259 & $52-233$ & 134 & 314 & 168 & 99 & 1 & 0.04 & 0.1 & 250 \\
\hline $\begin{array}{l}\text { São José do } \\
\text { Rio Preto }\end{array}$ & & Adamantina & 7695940 & 668800 & 68 & $28-68$ & 22 & 628 & 312 & 46 & 1.5 & 0.03 & 0.1 & 250 \\
\hline
\end{tabular}

Q: flow rate (considering 24-hour pumping); b: saturated thickness; K: hydraulic conductivity; i: hydraulic gradient; $\mathrm{n}_{\mathrm{ef}}$ : effective porosity; CFR: calculated fixed radius; UTM: Universal Transverse Mercator Coordinate System. 
case of a positive relation between N-Kjeldahl and TDS and chloride in several wells, these results were expected due to the common origin of these compounds.

\section{DISCUSSION}

This research found that the sewer network (Tab. 5) substantially influences nitrate concentrations; however, not homogeneously. In older occupation areas, where the sewer mains were installed until 2001, nitrate concentrations increased between 1994 and 2016, except in Cajobi, indicating leaks from the sewer network. Sewer mains were constructed in the ceramic material before 1990, which breaks down with age due to the lack of maintenance.

As to Clementina and Nova Independência, whose sewer networks were installed in 2013 and 2011, respectively, there

Table 5. Urban occupation in capture zones of the well.

\begin{tabular}{|c|c|c|c|c|c|c|c|c|}
\hline Town & $\begin{array}{l}\text { Number } \\
\text { of } \\
\text { buildings } \\
(1962)\end{array}$ & $\begin{array}{l}\text { Number } \\
\text { of } \\
\text { buildings } \\
(2016)\end{array}$ & $\begin{array}{c}\text { Area } \\
\left(\mathbf{k m}^{2}\right)\end{array}$ & $\begin{array}{c}\text { Urban } \\
\text { density- } \\
1962 \\
\text { (buildings/ } \\
\mathrm{km}^{2} \text { ) }\end{array}$ & $\begin{array}{c}\text { Urban } \\
\text { density - } \\
2016 \\
\text { (buildings/ } \\
\mathrm{km}^{2} \text { ) }\end{array}$ & $\begin{array}{c}\text { Evolution } \\
\text { of urban } \\
\text { density } \\
(\%)\end{array}$ & $\begin{array}{c}\text { Total urban } \\
\text { occupation } \\
\text { within } \\
\text { capture zone } \\
\text { in } 2016 \\
(\%)\end{array}$ & $\begin{array}{c}\text { Sewer } \\
\text { network } \\
\text { installation } \\
\text { year }\end{array}$ \\
\hline Andradina & 1.321 & 1.902 & 2.00 & 660 & 950 & +144 & 85 & $<1962$ \\
\hline Cajobi & 53 & 135 & 1.16 & 46 & 116 & +255 & 30 & 2001 \\
\hline Clementina & 125 & 304 & 0.51 & 243 & 590 & +243 & 60 & 2013 \\
\hline Flórida Paulista & 262 & 543 & 0.63 & 411 & 853 & +207 & 100 & $<1962$ \\
\hline Inúbia Paulista & 337 & 446 & 0.48 & 693 & 917 & +132 & 90 & $<1962$ \\
\hline Jales & 562 & 817 & 1.10 & 509 & 740 & +145 & 100 & $<2000$ \\
\hline Murutinga do Sul & 156 & 258 & 0.41 & 373 & 616 & +165 & 50 & 2010 \\
\hline Nova Independência & 132 & 488 & 1.84 & 71 & 264 & +264 & 45 & 2011 \\
\hline Pompéia & 63 & 273 & 0.31 & 204 & 882 & +882 & 70 & 2005 \\
\hline São José do Rio Preto & 243 & 1.775 & 1.23 & 196 & 1.435 & +1.435 & 100 & $<1995$ \\
\hline
\end{tabular}

\section{Pompéia}

1962

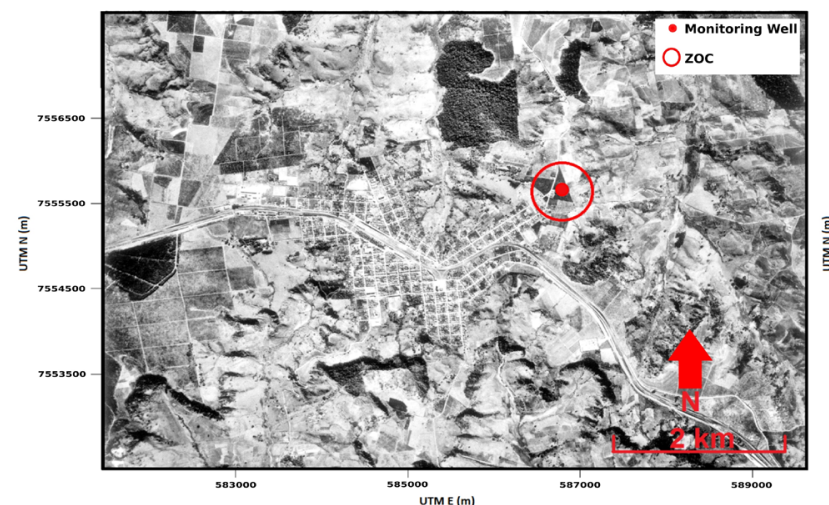

2016

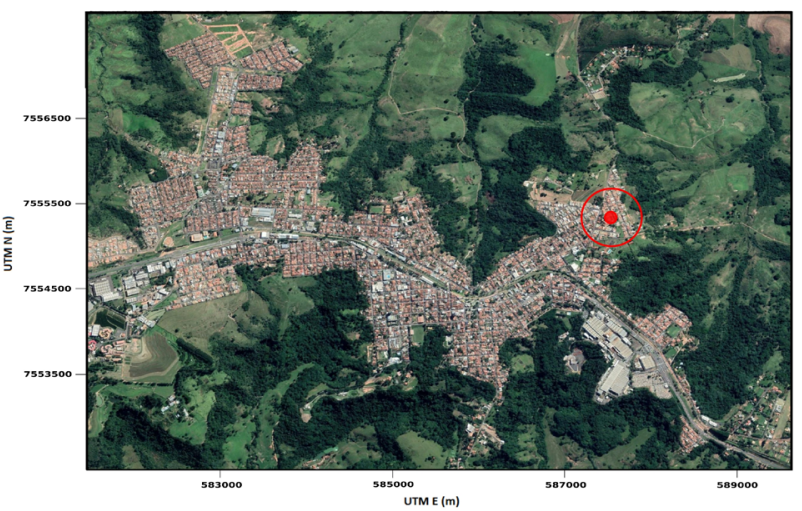

\section{Florida Paulista}

1962

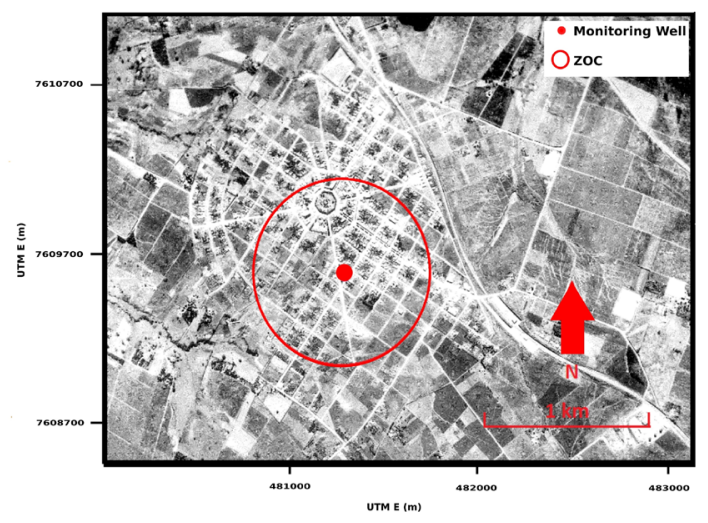

2016

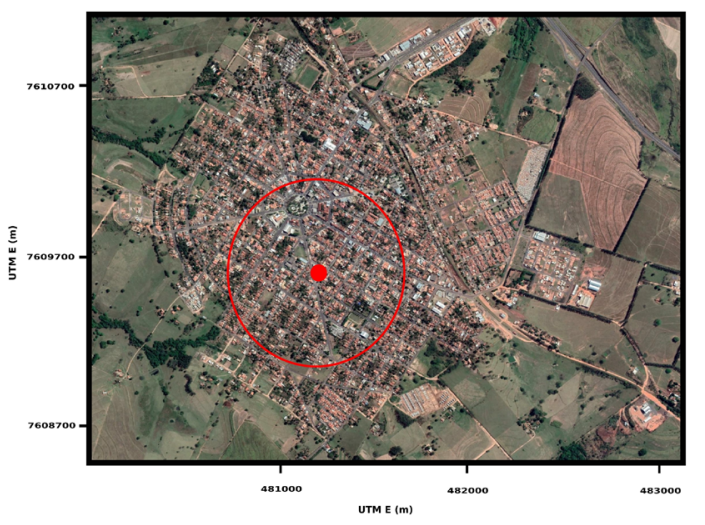

Figure 5. Evolution of capture zone occupation patterns. 
was an increase in nitrate due to a large number of buildings (with cesspools and septic tanks) built before the sewage collection network installation. In the future, the nitrate concentration will decrease due to the installation of those new sewer mains and the abandonment of pits.

All cities that tended to show increases in nitrate had direct associations with the number of buildings present within the capture zone in 2016, with greater than or equal to $60 \%$ of urban occupation in the capture zone (Fig. 6). If the well location is closer to the city center, that is, in older places, the occupation of the capture zone tends to be more significant.
The well located in Inúbia Paulista center showed stability in nitrate concentrations (6\% variation). Since 1962, the site has had a high urban density in the capture zone (693 houses/ $\mathrm{km}^{2}$ in 1962), reaching 917 houses $/ \mathrm{km}^{2}$ in 2016 . The well was installed in 1992 and had a concentration of $6.34 \mathrm{mg} / \mathrm{L} \mathrm{N}-\mathrm{NO}_{3}$, and in 2016, $7.00 \mathrm{mg} / \mathrm{L} \mathrm{N}-\mathrm{NO}_{-3}$ was measured.

Finally, the wells in the cities of Cajobi, Pompéia, and Murutinga do Sul showed a decrease in nitrate concentrations, although these locations presented an increase in the urban occupation density. In this group, the installation of the sewer mains occurred after 2001, and there was time for the contamination to be reduced, showing that modern

Table 6. Parameters including the main positive and negative values, analyzed according to Pearson's correlations.

\begin{tabular}{|c|c|c|c|}
\hline \multirow{2}{*}{ Nitrate variation of time } & \multirow{2}{*}{ Town } & \multicolumn{2}{|c|}{ Correlation } \\
\hline & & Positive & Negative \\
\hline \multirow{6}{*}{ Increase } & Andradina & $\begin{array}{l}\text { Total dissolved solids: } \rho=1.0 \\
\text { Total resistivity: } \rho=0.8\end{array}$ & $\begin{array}{l}\text { Lithium: } \rho=-0.9 \\
\text { Titanium: } \rho=-0.5\end{array}$ \\
\hline & Clementina & $\begin{array}{l}\text { Air temperature: } \rho=0.7 \\
\text { Kjeldahl nitrogen: } \rho=0.5\end{array}$ & $\begin{array}{l}\text { Lithium: } \rho=-0.6 \\
\text { Uranium: } \rho=-0.6\end{array}$ \\
\hline & Flórida Paulista & $\begin{array}{c}\text { Kjeldahl nitrogen: } \rho=0.5 \\
\text { Total dissolved solids: } \rho=0.7\end{array}$ & Silver: $\rho=-0.9$ \\
\hline & Jales & Antimony: $\rho=0.8$ & $\begin{array}{l}\text { Bicarbonate alkalinity: } \rho=-0.8 \\
\text { Hexavalent chromium: } \rho=-0.7\end{array}$ \\
\hline & Nova Independência & $\mathrm{pH}: \rho=0.7$ & $\begin{array}{l}\text { Silver: } \rho=-0.7 \\
\text { Tin: } \rho=-0.7\end{array}$ \\
\hline & São José do Rio Preto & $\begin{array}{c}\text { Chloride: } \rho=0.7 \\
\text { Kjeldahl nitrogen: } \rho=0.7\end{array}$ & Sulfate: $\rho=-0.8$ \\
\hline \multirow{3}{*}{ Decrease } & Cajobi & $\begin{array}{l}\text { Total dissolved solids: } \rho=0.6 \\
\text { Total resistivity: } \rho=0.8\end{array}$ & Uranium: $\rho=-0.6$ \\
\hline & Murutinga do Sul & Chloride: $\rho=0.6$ & $\begin{array}{l}\text { Antimony: } \rho=0.7 \\
\text { Tin: } \rho=-0.8\end{array}$ \\
\hline & Pompéia & Lithium: $\rho=0.6$ & $\begin{array}{l}\text { Fluoride: } \rho=-0.7 \\
\text { Silver: } \rho=-0.8\end{array}$ \\
\hline Stable & Inúbia Paulista & Total solids: $\rho=0.7$ & $\begin{array}{l}\text { Lithium: } \rho=-0.7 \\
\text { Titanium: } \rho=-0.8\end{array}$ \\
\hline
\end{tabular}

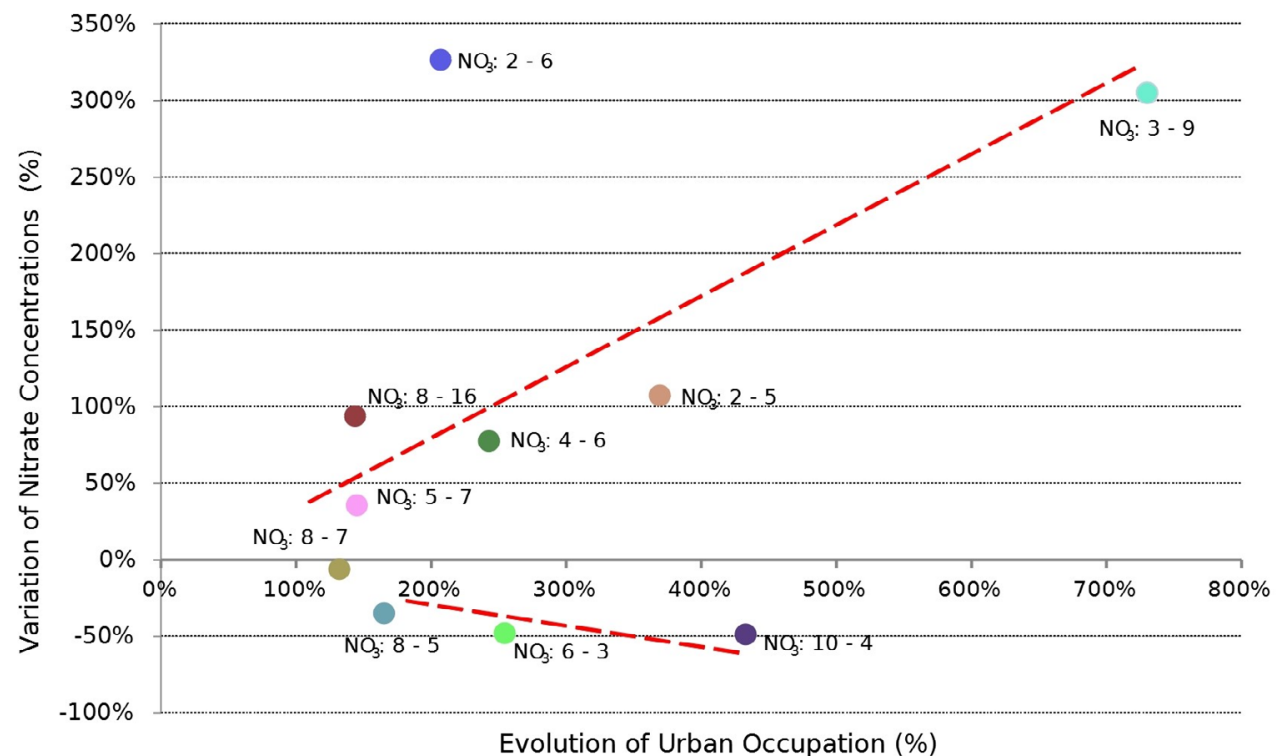

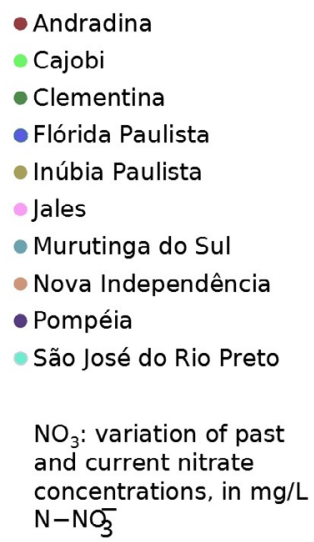

Figure 6. Variation of nitrate concentrations according to the evolution of occupation in each analyzed well. The dashed lines in the red color indicate the trends of nitrate concentrations: increase or reduction of concentrations. 
and efficient networks are essential to minimize the aquifer contamination.

\section{CONCLUSION}

The method applied to the BAS showed a correlation between the urban land use in the well vicinity (capture zone) and changes in the concentration of nitrate in groundwater between 1994 and 2016. In areas with sewer mains built before 2001 and with an urban density greater than $60 \%$ of urban occupation in the capture zone, there might have been an increase of at least $35 \%$ in the nitrate concentration.

Although the implementation of a public sewage system is the most efficient way to reduce contamination by domestic effluents, the lack of maintenance, mostly of old ceramic networks, has caused leaks that deteriorate the BAS waters.

This study demonstrates that the method established a causal relationship between the history of urban occupation and the nitrate concentration in monitoring wells in an unconfined and sedimentary aquifer, such as the BAS. Thus, it would be desirable to extend the application to all the other wells in the state monitoring network. This method could also be applied to select new locations for future wells that will integrate this network.

The results of such a method could be used by health surveillance agencies, which should pay attention to public-supply wells in areas where urban density is more significant than $60 \%$ of urban occupation in the capture zone and sewer networks were built before the 2000s.

Finally, any urban expansion should be preceded with the installation of a sewer network, using materials that are more resistant to time, such as PVC, followed by an efficient and permanent maintenance program, as can be seen in the cities of Murutinga do Sul and Pompeia.

\section{ACKNOWLEDGEMENTS}

The authors want to express their thanks to Geographer Rosângela Modesto of CETESB for releasing the data and her careful manuscript reading. We are also grateful to Fundação de Amparo à Pesquisa do Estado de São Paulo (FAPESP) for supporting the research projects that helped this study interpretations (Proc. 2014/05697-2; 2013/22469-0).

\section{ARTICLE INFORMATION}

Manuscript ID: 20200053. Received on: 06/23/2020. Approved on: 01/21/2021.

F.P.: conceptualization, data curation, investigation, methodology, writing; R.H.: project coordination, supervision, conceptualization; N.A.: data curation, investigation, writing; B.C.: data curation, investigation, writing. Competing interests: The authors declare no competing interests.

\section{REFERENCES}

Aranda N., Prado R., Elis V., Miguel M., Gandolfo O., Conicelli B. 2019. Evaluating elastic wave velocities in Brazilian municipal solid waste. Environmental Earth Sciences, 78:475. https://doi.org/10.1007/ s12665-019-8490-y

Babinski M., Aily C., Ruiz I.R., Sato K. 2003. Pb isotopic signatures of the atmosphere of the São Paulo city, Brazil. Journal de Physique, 107:87-90. https://doi.org/10.1051/jp4:20030250

Babinski M., Gioia S.M.L., Aily C., Pimentel M., Ruiz I.R., Kerr A. 2012. Aplicação da geoquímica isotópica do $\mathrm{Pb}$ na caracterização das fontes poluentes na atmosfera: Exemplos das cidades de São Paulo e Brasília. In: Figueiredo B.R., De Capitani E.M., Dos Anjos J.Â.S.A., Luiz-Silva W. (Eds.). Chumbo, ambiente e saúde: o desafio do controle da exposição humana. São Paulo: Annablume, p. 185-213.

Barcha S.F. 1980. Aspectos gemológicos e províncias hidrogeológicas da Formação Bauru na região norte-ocidental do Estado de São Paulo. São José do Rio Preto: Universidade Estadual Paulista "Júlio de Mesquita Filho", 209 p.

Bertolo R.A., Bourotte C., Marcolan L., Oliveira S.B., Hirata R.C.A. 2011. Anomalous content of chromium in a Cretaceous sandstone aquifer of the Bauru Basin, state of São Paulo, Brazil. Journal of South American Earth Sciences, 31(1):69-80. https://doi.org/10.1016/j.jsames.2010.10.002

Bertolo R., Hirata R., Conicelli B., Simonato M., Pinhatti A., Fernandes A. 2015. Água subterrânea para abastecimento público na Região Metropolitana de São Paulo: é possível utilizá-la em larga escala? Revista DAE, 63:6-17. https://doi.org/10.4322/dae.2014.148

Bourotte C., Bertolo R.A., Almodovar M., Hirata R. 2009. Natural occurrence of hexavalent chromium in a sedimentary aquifer in Urânia, State of São Paulo, Brazil. Anais da Academia Brasileira de Ciências, 81(2):227242. https://doi.org/10.1590/S0001-37652009000200009
Carvalho A.M., Hirata R. 2012. Avaliação para a proteção dos poços de abastecimento público do Estado de São Paulo. Geologia USP. Série Científica, 12(1):5-70. https://doi.org/10.5327/Z1519-874X2012000100005

Cary L., Petelet-Giraud E., Montenegro S., Hirata R., Martins V., Aurouet A., Pauwels H., Kloppmann W., Aquilina L. 2013. Groundwater Salinization in a Coastal Multilayer Aquifer: Preliminary Results on Origins and Mechanisms- Example of Recife (Brazil). Procedia Earth and Planetary Science, 7:118-122. https://doi.org/10.1016/j.proeps.2013.03.164

Companhia Ambiental do Estado de São Paulo (CETESB). 2013. Qualidade das águas subterrâneas do Estado de São Paulo 2010-2012. São Paulo: Série de Relatórios/Secretaria de Estado do Meio Ambiente, 242 p. Relatório técnico.

Companhia Ambiental do Estado de São Paulo (CETESB). 2016. Qualidade das Águas Subterrâneas no Estado de São Paulo 2013-2015. São Paulo: Série de Relatórios/Secretaria de Estado do Meio Ambiente, 308 p. Relatório técnico.

Companhia Ambiental do Estado de São Paulo (CETESB). 2019. Qualidade das Águas Subterrâneas no Estado de São Paulo 2016-2018. São Paulo: Série de Relatórios/Secretaria de Estado do Meio Ambiente, 291 p. Relatório técnico.

Conicelli B. 2014. Gestão das águas subterrâneas na Bacia Hidrográfica do Alto Tietê (SP). Thesis, Instituto de Geociências, Universidade de São Paulo, São Paulo. https://doi.org/10.11606/T.44.2014.tde-09102014-140000

Departamento de Águas e Energia Elétrica (DAEE). 2005. Mapa de águas subterrâneas do estado de São Paulo. 119 p. +1 mapa +1 CD. Escala 1:1.000.000. São Paulo: Departamento de Águas e Energia Elétrica.

Departamento de Águas e Energia Elétrica (DAEE). 2012. Projeto Jurubatuba: restrição e controle de uso de água subterrânea. In: Departamento de Águas e Energia Elétrica, Instituto Geológico, Secretaria de Estado do Meio Ambiente, Secretaria de Estado de Saneamento e Energia. In: Cadernos do Projeto Estratégico Aquiferos. São Paulo: Secretaria de Estado de Saneamento e Energia, 109 p. 
Drake V.M., Bauder J.W. 2005. Groundwater nitrate-nitrogen trends in relation to urban development, Helena Montana, 1971-2003. Groundwater Monitoring and Remediation, 25(2):118-130. https://doi. org/10.1111/j.1745-6592.2005.0017.x

Foster S., Gomes D.C. 1989. Monitoreo de la calidad de las aguas subterráneas: una evaluación de métodos y costos. Lima: WHO-PAHO/HPE-CEPIS, 111 p. Technical Manual.

Foster S., Hirata R. 1988. Groundwater pollution risk assessment: a methodology using available data. Lima: WHO-PAHO-HPE CEPIS. Technical Manual.

Foster S., Hirata R., Howard K. 2011. Groundwater use in developing cities Policy issues arising from current trends. Hydrogeology Journal, 19:271-274.

Foster S., Hirata R., Gomes D., Délia M., Paris M. 2006. Proteção da qualidade da água subterrânea: um guia para empresas de abastecimento de água, órgãos municipais e agências ambientais. Washington, D.C.: Banco Mundial.

Freedman D., Pisani R., Purves R. 2007. Statistics (international student edition). $4^{\text {th }}$ ed. New York: W. W. Norton and Company.

Giafferis G., Oliveira E. 2006. Investigação da qualidade de águas subterrâneas no município de Bauru. In: Congresso Brasileiro de Águas Subterrâneas, 14., 2006, Curitiba. Annals... Curitiba: ABAS. (CD-ROM).

He S., Wu J. 2019. Hydrogeochemical Characteristics, Groundwater Quality, and Health Risks from Hexavalent Chromium and Nitrate in Groundwater of Huanhe Formation in Wuqi County, Northwest China. Exposure and Health, 11:125-137. https://doi.org/10.1007/s12403-018-0289-7

Hibbs B.J., Sharp J.M. Jr. 2012. Hydrogeological effects of urbanization. Environmental and Engineering Geoscience, 18(1):3-24

Hirata R. 2000. Estudo da contaminação por nitrato no Distrito de Tibiriça, Bauru. São Paulo: Departamento de Água, Energia e Esgoto. Instituto de Geociências, Universidade de São Paulo.

Hirata R., Foster S., Oliveira F. 2015. Águas subterrâneas urbanas: avaliação para uma gestão sustentável [Urban groundwater: evaluation for sustainable management]. 1São Paulo: Instituto de Geociências / FAPESP, 2015, 112 p.v. 1.

Hirata R., Suhogusoff A.V. 2019. How much do we know about the groundwater quality and its impact on Brazilian society today? Acta Limnologica Brasiliensia, 31:e109. https://doi.org/10.1590/s2179-975x4419

Paula e Silva F. 2003. Geologia de subsuperfície e hidroestratigrafia do Grupo Bauru no estado de São Paulo. Thesis, Instituto de Geociências e Ciências Exatas, Universidade Estadual Paulista "Júlio de Mesquita Filho", Rio Claro, 166 p.

Petelet-Giraud E., Cary L., Cary P., Bertrand G., Giglio-Jacquemot A., Hirata R., Aquilina L., Alves L., Martins V., Melo A., Montenegro S., Chatton E., Franzen M., Aurouet A. 2018. Multi-layered water resources, management, and uses under the impacts of Global Changes in a Southern Coastal Metropolis: when will it be already too late? Crossed analysis in
Recife, NE Brazil. Environmental Science and Policy, 618:645-657. https:// doi.org/10.1016/j.scitotenv.2017.07.228

Porto M. 2003. Recursos Hídricos e Saneamento na Região Metropolitana de São Paulo. Brasília: Banco Mundial, 73. v. 1.

Reynolds-Vargas J., Fraile-Merino J., Hirata R. 2006. Trends in nitrate concentrations and determination of their origin using stable isotopes ( $18 \mathrm{O}$ and $15 \mathrm{~N}$ ) in groundwater of the Western Central Valley, Costa Rica. Journal of the Human Environment, 35(5):229-236.

Santos Filho M., Hirata R., Luiz M.B., Conicelli B. 2017. Solo e águas subterrâneas contaminadas pela deposição de resíduos sólidos urbanos: o caso do Vazadouro de Tatuí (SP). Revista do Instituto Geológico, 38(1):3147. https://doi.org/10.5935/0100-929X.20170003

Sistema Nacional de Informações sobre Saneamento (SNIS). 2017. Diagnóstico dos Serviços de Água e Esgotos - 2015. 21ª ed. Brasília: Secretaria Nacional de Saneamento Ambiental, 212 p.

São Paulo. Secretaria da Agricultura do Estado de São Paulo. 1962. Levantamento aerofotogramétrico do Estado de São Paulo. São Paulo: Instituto Agronômico.

Tavares T.L.S., Bertolo R.A., Fiúme B., Crespi A.M., Martins V., Hirata R. 2015. Hydrochemical investigation of barium in the public water supply wells of Sao Paulo state, southern Brazil. Environmental Earth Sciences, 74(9):6599-6612. https://doi.org/10.1007/s12665-015-4661-7

U.S. Environmental Protection Agency (USEPA). 1994. Ground water and wellhead protection. EPA/625/R-94/001. Cincinatti: USEPA, Office of Research and Development.

Varnier C., Iritani M.A., Viotti M., Oda G.H., Ferreira L.M.R. 2010. Nitrato nas águas subterrâneas do Sistema Aquífero Bauru, área urbana do município de Marília (SP). Revista do Instituto Geológico, São Paulo, 31(12):1-21. https://doi.org/10.5935/0100-929X.20100001

Varnier C., Rocha G.A., Campos J.E., Albuquerque Filho J.L., Simonato M., Hirata R. 2019. Nitrato nas águas subterrâneas: desafios frente ao panorama atual. São Paulo: SIMA/IG, 99 p. v. 1.

$\mathrm{Xu}$ Y., Baker L.A., Johnson P.C. 2007. Trends in groundwater nitrate contamination in the Phoenix, Arizona Region. Groundwater Monitoring and Remediation, 27(2):49-56.https://doi.org/10.1111/j.1745-6592.2007.00135.x

Xu Z., Xu J., Yin H.J.W., Jin W., Li H., He Z. 2019. Urban river pollution control in developing countries. Nature Sustain, 2:158-160. https://doi. org/10.1038/s41893-019-0249-7

Wu J., Li P., Wang D., Ren X., Wei M. 2020. Statistical and multivariate statistical techniques to trace the sources and affecting factors of groundwater pollution in a rapidly growing city on the Chinese Loess Plateau. Human and Ecological Risk Assessment, 26(6):1603-1621. https://doi.org/10.1080 /10807039.2019.1594156 